\title{
Penerapan Model TTW Berbantuan Media Gambar Meningkatkan Hasil Belajar Bahasa Indonesia
}

\author{
Made Wruh Dharwisesa ${ }^{1 *}$, I Wayan Widiana ${ }^{2}$, I Made Tegeh ${ }^{3}$ iD \\ 1,2 Prodi Pendidikan Guru Sekolah Dasar, Universitas Pendidikan Ganesha, Singaraja, Indonesia \\ ${ }^{3}$ Prodi Teknologi Pembelajaran, Universitas Pendidikan Ganesha, Singaraja, Indonesia \\ *Corresponding author: ecixsita@gmail.com
}

\begin{abstract}
Penelitian ini bertujuan untuk menganalisis adanya perbedaan hasil belajar yang signifikan antara kelompok siswa yang diterapkan dengan model pembelajaran TTW berbantuan media gambar dengan kelompok siswa yang diterapkan dengan model pembelajaran konvensional pada siswa kelas IV. Penelitian ini dilakukan karena masih rendahnya hasil belajar Bahasa Indonesia pada siswa SD kelas IV. Penelitian ini merupakan quasi experiment dengan rancangan non equivalent post test only control group design. Populasi penelitian ini adalah siswa kelas IV SD, yang berjumlah 5 kelas dengan siswa 131 orang. Sampel penelitian ini yaitu siswa kelas IV SD Negeri 1 Patas dengan jumlah siswa 44 orang dan siswa kelas IV SD Negeri 3 Patas dengan jumlah siswa 42 orang, yang ditentukan dengan teknik simplerandom sampling. Instrumen pada penelitian ini yaitu lembar observasi dan tes menulis. Data yang diperoleh dianalisis dalam dua tahap, yaitu analisis statistik deskriptif dan analisis statistik inferensial (uji-t). Hasil penelitian menunjukkan bahwa terdapat perbedaan hasil belajar antara kelompok siswa yang dibelajarkan dengan model pembelajaran TTW berbantuan media gambar dengan kelompok siswa yang dibelajarkan dengan pembelajaran konvensional, dengan nilai thitung sebesar 35,71 dan tab sebesar 2,000. Berdasarkan hasil penelitian tersebut, model pembelajaran TTW berbantuan media gambar dapat meningkatkan hasil belajar Bahasa Indonesia pada siswa kelas IV SD.
\end{abstract}

Keywords: TTW, Media Gambar, Hasil Belajar.

\section{Abstract}

This study aims to analyze the existence of significant differences in learning outcomes between groups of students who are applied by a learning model TTW and aided drawing media with and the group of students who are applied with conventional learning models in fourth grade students. This study was conducted because of the low learning outcomes of Indonesian Language in fourth grade elementary school students. This study is a quasi experimental design with non equivalent post test and only control group design. The population of this study were students of fourth grade elementary school, which amounted to 5 classes with 131 students. The sample of this research is the fourth grade students of elementary school 1 Patas with 44 students and the fourth grade students of elementary school 3 Patas with the number of students 42 people, which is determined by the simple random sampling technique. The instruments in this study were the observation sheet and writing test. The data obtained were analyzed in two stages, namely descriptive statistical analysis and inferential statistical analysis (t-test). The results showed that there were differences in learning outcomes between groups of students who were taught with the TTW learning model assisted by drawing media with groups of students who were taught using conventional learning, with tcount of 35.71 and ttab of 2,000. Based on the results of this study, the TTW learning model assisted by drawing media can improve Indonesian learning outcomes in fourth grade elementary school students.

Keywords: $T T W$, Drawing Media, Learning Outcomes

$\begin{array}{lll}\text { History: } & & \text { Publisher: Undiksha Press } \\ \text { Received } & \text { : 2 Juni } 2020 & \text { Licensed: This work is licensed under } \\ \text { Revised } & : \text { J Juli } 2020 & \text { a Creative Commons Attribution 3.0 License } \\ \text { Accepted } & : 6 \text { Juli } 2020 & \end{array}$




\section{Introduction}

Bahasa Indonesia sebagai alat komunikasi dalam kehidupan sehari-hari sangat penting bagi masyarakat Indonesia. Oleh karena itu maka kemampuan berbahasa setiap individu merupakan dasar yang fundamental dalam menjalani interaksi sosial. Hal ini yang mendasari pemberian mata pelajaran Bahasa Indonesia dalam dunia pendidikan menjadi sarana yang penting dalam mengembangkan kemampuan berbahasa khususnya masyarakat Indonesia apabila dikaitkan dengan pendidikan di sekolah. Bahasa Indonesia merupakan mata pelajaran yang sangat penting di sekolah, bukan saja karena Bahasa Indonesia adalah alat komunikasi yang terpenting dalam masyarakat, melainkan karena penguasaan Bahasa Indonesia yang baik sangat membantu siswa untuk memahami mata pelajaran lain. Oleh karena itu, pelajaran Bahasa Indonesia yang sifatnya gramatikasentris tidak akan berhasil menjadikan siswa terampil menggunakan bahasa, bila siswa tersebut tidak diberikan kesempatan untuk berlatih menggunakan bahasa yang sudah dipelajari.

Susanto (2013) menyatakan bahwa keterampilan berbahasa yang baik merupakan salah satu keterampilan yang diharapkan dimiliki oleh siswa selama berada pada jenjang sekolah dasar. Pembelajaran Bahasa Indonesia terutama di tingkat sekolah dasar tidak akan terlepas dari empat keterampilan berbahasa, yaitu menyimak, berbicara, membaca, dan menulis. Ia juga mengatakan bahwa keempat keterampilan berbahasa tersebut sangat mempengaruhi hasil belajar Bahasa Indonesia. Pendidikan dasar atau sekolah dasar merupakan momentum awal bagi anak untuk kemampuan dirinya. Pemikiran sejalan juga di sampaikan oleh Badan Standar Pendidikan Nasional (BNSP, 2006) mereka mengatakan bahwa standar isi Bahasa Indonesia diarahkan untuk mengembangkan kemampuan peserta didik untuk berkomunikasi dengan bahasa yang baik dan benar secara lisan maupun tertulis serta menumbuhkan apresiasi terhadap hasil karya kesusastraan manusia Indonesia.

Namun pada kenyataannya, berdasarkan pengamatan peneliti pada tanggal 5 Pebruari 2018, hasil UTS siswa kelas IV pada semester Ganjil rata-rata hasil belajar Bahasa Indonesia di SD Gugus III Kecamatan Gerokgak masih rendah. Hal ini ditunjukkan dari data nilai ratarata yang diperoleh siswa kelas IV di SD N 1 Patas sebesar 67,46, SD N 2 Patas sebesar 66,46, SD N 3 Patas sebesar 65,86, SD N 4 Patas sebesar 66,11 sedangkan SDN 5 Patas memperoleh angka 66,80 dengan KKM masing-masing sekolah sebesar 70. Hasil belajar Bahasa Indonesia siswanya masih rendah dikarenakan aspek menulis, berbicara dan menyimak siswa masih sangat kurang. Mengingat proses pembelajaran yang dilakukan di dalam kelas masih menggunakan metode ceramah, penggunaan media pembelajaran sangat minim dan berpusat pada guru menyebabkan pelajaran Bahasa Indonesia dianggap sebagai pelajaran yang membosankan. Siswa cenderung mengantuk dan jenuh dalam menerima pembelajaran Bahasa Indonesia di dalam kelas, sehingga memberikan dampak pada rendahnya hasil belajar Bahasa Indonesia siswa kelas IV SD di gugus III Kecamatan Gerokgak.

Untuk meningkatkan hasil belajar siswa kelas IV SD di gugus III kecamatan Gerokgak, maka guru dituntut mengemas pembelajaran Bahasa Indonesia lebih menarik sehingga dapat digemari oleh siswa. Proses pembelajaran yang penuh inovasi, aktif dan kreatif sangat diperlukan agar siswa bisa mengikuti proses belajar dengan baik. Salah satunya dengan menerapkan model pembelajaran yang dapat melibatkan siswa secara aktif dalam proses pembelajaran sehingga berdampak pada peningkatan hasil belajar Bahasa Indonesia siswa kelas IV SD di gugus III Kecamatan Gerokgak. Salah satu model pembelajaran tersebut adalah Model Think Talk Write (TTW).

Sehingga tujuan dalam penelitian ini untuk mengetahui perbedaan yang signifikan dari hasil belajar Bahasa Indonesia antara kelompok siswa yang diterapkan model pembelajaran Think Talk Write (TTW) berbantuan media gambar dengan kelompok siswa 
yang diterapkan dengan model pembelajaran konvensional pada siswa SD kelas IV semester genap tahun pelajaran 2017/2018 di Gugus III Kecamatan Gerokgak.

Menurut Huda (2014) model pembelajaran Think Talk Write (TTW) merupakan salah satu strategi pembelajaran yang membantu melatih kemampuan berbicara dan menulis siswa dengan lancar. Huiker dan Laughlin sebagai penemu model pembelajaran Think Talk Write (TTW) juga mengatakan hal mendasar dalam model pembelajaran ini bahwa belajar merupakan sebuah perilaku sosial. Model Think Talk Write (TTW) memotivasi siswa dalam berpikir, berbicara dan menulis suatu permasalah tertentu. Model ini juga dipergunakan dalam melatih kemampuan siswa dalam berbahasa dan kemudian dikembangkan dalam bentuk tulisan. Selain itu, model Think Talk Write (TTW) memperkenankan siswa untuk mengumpulkan dan mengolah ide dalam pikirannya sebelum mengutarakannya dalam bentuk tulisan atau melalui percakapan terstruktur (Kurniawati, 2018).

Model pembelajaran Think Talk Write (TTW) pada dasarnya di bangun melalui tiga tahap yaitu, berpikir, berbicara dan menulis (Huda, 2014). Think, pada tahap ini siswa disuguhkan dengan wacana dalam bentuk soal atau permasalahan yang berhubungan dengan kehidupan sehari-hari atau kontekstual. Kemudian secara mandiri atau individu siswa memikirkan cara penyelesaiannya, menulis catatan-catatan kecil mengenai ide pokok dalam wacana dan beberapa hal yang belum dimengerti dengan bahasanya sendiri. Talk, pada tahap ini siswa mendapatkan kesempatan mendiskusikan ide pikiran yang telah didapatnya pada tahap sebelumnya dengan teman kelompoknya. Siswa bernegosiasi, menyusun, menguji serta bertukar pendapat dengan temannya dalam kegiatan diskusi kelompok. Perkembangan penggunaan bahasa siswa akan dapat terlihat ketika siswa berdialog, bertukar pendapat dan bernegoisasi dengan orang lain. Write, hasil dari pemikiran dalam berdiskusi pada tahap Think dan Talk. Pada tahap ini siswa menuangkan tulisannya berdasarkan tema yang pelajari, keterkaitan dengan konsep pembelajaran sebelumnya, metode dan cara penyelesaian yang diperolehnya (Amirul, 2017). Sejalan dengan itu, Silver dan Smith (dalam Hikmawati, 2013) memberikan pendapat bahwa penerapan model Think Talk Write (TTW) dalam proses pembelajaran akan berjalan dengan efektif apabila seorang guru mampu membuat dan menyajikan materi yang memungkinkan siswa berpikir aktif, memotivasi dan memperhatikan dengan seksama hasil pemikiran siswa yang diungkapkan secara lisan dan tulisan, mendampingi dan memfasilitasi dalam kegiatan berdiskusi siswa, menganalisa, menilai dan memotivasi siswa agar bisa ikut terlibat dalam diskusi. Mereka juga mengatakan, tugas yang disiapkan diharapkan mampu memotivasi kreatifitas siswa untuk bekerja secara aktif, seperti soal-soal yang mampu memunculkan pemikiran-pemikiran baru.

Menurut Suyatno (dalam Fitri, 2016) Model Pembelajaran Think Talk Write (TTW) dimulai dari tahap berpikir berdasarkan wacana yang kemudian disimak, dikritisi dan dicarikan alternatife solusi, hasil berpikir selanjutnya dipresentasikan. Sintaknya adalah membaca, presentasi, diskusi dan melaporkan. Proses belajar mengajar dengan model ini menyatukan keahlian siswa dalam berpikir, berbicara dan menulis.

Menurut Ainiyah (2017) Tahapan dalam pelaksanaan pembelajaran dengan model pembelajaran Think Talk Write (TTW) dirancang dengan matang dimana langkah yang pertama, siswa disuguhkan teks dan menulis catatan kecil secara invidual (Think) untuk di diskusikan dalam kelompok. Tahap kedua, siswa berkomunikasi dengan teman dalam satu kelompok untuk membahas isi catatan (Talk). Dalam berdiskusi siswa mengungkapkan pendapat dan idenya dengan bahasa dan kata-katanya sendiri. Diskusi ini akan membangun pengetahuan dan pemahaman siswa sehingga dalam berdiskusi diharapkan dapat menghasilkan penyelesaian masalah yang telah diberikan guru. Tahap berikutnya, siswa mulai membangun dan mengembangkan pengetahuannya sendiri mengenai materi pembelajaran dalam bentuk tulisan (Write). Kegiatan tahap akhir, masing-masing kelompok menunjuk wakilnya untuk menyajikan jawabannya dan kelompok lain memberikan 
tanggapan. Guru dan siswa bersama-sama merefleksi dan menyimpulkan materi yang telah dipelajari.

Selain penggunaan model pembelajaran yang inovatif dan kreatif, penggunaan media pembelajaran dalam proses belajar mengajar Bahasa Indonesia juga tidak kalah penting untuk menarik minat siswa dalam belajar. Selain itu guru dituntut untuk memiliki kemampuan menggunakan media pembelajaran, kemampuan guru dalam membuat media pembelajaran juga penting apabila media pembelajaran belum tersedia di sekolah (Arsyad, 2009). Media merupakan salah satu pendukung penting dalam proses pembelajaran. Secara harfiah kata media berasal dari bahasa latin yaitu medius yang memiliki arti tengah, perantara atau pengatar. Sedangkan dalam Bahasa Arab, media memiliki arti perantara atau pengantar pesan dari pengirim kepada penerima pesan (Santyasa, 2007). Media pembelajaran yang paling sering digunakan di dalam kelas salah satunya adalah media visual dalam bentuk gambar. Gerlach dan Evy (dalam Mustika, 2016) menyatakan bahwa media merupakan manusia, materi atau kejadian yang membangun kondisi sehingga membuat siswa mampu memperoleh pengetahuan, keterampilan atau sikap. Menurut Sudjana (dalam Agustina, 2017) bahwa media gambar merupakan media visual dalam bentuk grafis. Ia juga mendefinisikan Media grafis selaku media yang mengkombinasikan fakta dan ide secara lisan dan kuat melalui suatu kombinasi penggunaan kata-kata dan gambar-gambar sehiggga proses pembelajaran dengan media gambar mampu membuat pelajaran Bahasa Indonesia lebih menarik minat siswa di dalam kelas. Keberhasilan penggunaan media berbasis visual di tentukan oleh kualitas dan efektivitas bahan-bahan visual dan grafik itu. Hal ini hanya dapat dicapai dengan mengatur dan mengorganisasikan gagasan-gagasan yang timbul, merencanakannya dengan seksama, dan menggunakan teknik-teknik dasar visualisasi objek, konsep, informasi, atau situasi. Meskipun perancang media pembelajaran bukan seorang pelukis dengan latar belakang profesional, ia sebaiknya mengetahui beberapa prinsip dasar dan penuntun dalam rangka memenuhi kebutuhan penggunaan media berbasis visual. Dengan kata lain media gambar merupakan media visual seperti halnya guru, buku teks, dan lingkungan sekolah sebagai media pembelajaran untuk menciptakan pembelajaran yang lebih efektif. Dengan menggunakan media gambar dalam proses pembelajaran dapat memberikan kelebihan berupa dengan gambar siswa dapat lebih nyata dalam memahami materi yg belum pernah dilihatnya, mampu mempermudah guru dalam mengenalkan sesuatu tanpa harus melihat objek ke tempat langsung, meminimalisir kesalahpahaman siswa dalam memahami sesuatu dan disamping itu media gambar lebih terjangkau dari segi harga dan mudah di bawa (Putra, 2011).

Berdasarkan hal tersebut maka peneliti ingin mengkaji pengaruh dari penerapan model pembelajaran Think Talk Write (TTW) berbantuan media gambar terhadap hasil belajar Bahasa Indonesia pada siswa SD kelas IV melalui penelitian yang berjudul "Penerapan Model Pembelajaran Think Talk Write (TTW) Berbantuan Media Gambar Terhadap Hasil Belajar Bahasa Indonesia”.

\section{Materials and Methods}

Pada penelitian menggunakan penelitian eksperimen semu (Quasi Eksperiment). Penelitian eksperimen semu, tidak dilakukan penempatan subjek secara acak ke dalam kelompok yang dibandingkan karena individu subjek sudah terdapat dalam kelompok yang dibandingkan sebelum penelitian dilaksanakan. Desain penelitian menggunakan eksperimen Non-Equivalent Post-test Only Control Group Design. Desain penelitian eksperimen NonEquivalent Post - test Only Control Group Design dipilih karena subjek eksprimen tidak dirandomisasi untuk menentukan sampel dan ditempatkan dalam kelompok eksperimen dan kelompok kontrol. Desain ini menggunakan satu kelompok eksperimen dan satu kelompok 
kontrol. Kelompok eksperimen mendapatkan perlakuan, dan setelah itu diberi post-test. Sedangkan kelompok kontrol hanya diberi post-test tanpa diberikan perlakuan.

Populasi dalam penelitian adalah seluruh siswa kelas IV SD di Gugus III Kecamatan Gerokgak tahun pelajaran 2017/2018. Jumlah keseluruhan anggota populasi pada penelitian ini berjumlah 131 orang. Mengingat jumlah populasi sangat banyak berdasarkan pertimbangan efesiensi maka tidak semua populasi dapat di teliti, tetapi untuk mewakili seluruh populasi akan dipilih beberapa siswa saja. Dari 5 SD yang ada di gugus III dilakukan uji kesetaraan untuk menentukan sampel setara atau tidak.

Uji kesetaraan dilakukan menggunakan nilai ulangan tengah semester (UTS) ganjil mata pelajaran Bahasa Indonesia siswa SD kelas IV dengan menggunakan analisis ANAVA satu jalur. Hasil dari uji kesetaraan pada populasi didapatkan semua sekolah setara yaitu SD Negeri 1 Patas, SD Negeri 2 Patas, SD Negeri 3 Patas, SD Negeri 4 Patas dan SD Negeri 5 Patas. Dalam penelitian ini untuk menentukan subjek penelitian mengunakan teknik simple random sampling. Dengan teknik simple random sampling setiap siswa memiliki peluang atau kesempatan yang sama untuk dijadikan subjek penelitian. Sampel yang ditetapkan dalam penelitian ini adalah siswa kelas IV SD Negeri 1 Patas yang berjumlah 44 siswa sebagai kelas eksperimen dan Kelas IV SD Negeri 3 Patas berjumlah 42 siswa sebagai kelas control. Kelas eksperimen diberikan perlakuan pembelajaran dengan model Think Talk Write (TTW) dan kelas kontrol diberikan perlakuan pembelajaran dengan model pembelajaran konvensional.

Penelitian ini melibatkan dua variabel yaitu variabel bebas dan variabel terikat. Variabel bebas dalam penelitian ini adalah model Think Talk Write (TTW) dan model pembelajaran konvensional sedangkan variabel terikatnya adalah Hasil Belajar Bahasa Indonesia. Teknik pengumpulan data dalam penelitian ini adalah menggunakan Lembar Observasi dan tes. Lembar Observasi digunakan saat kegiatan siswa membaca, sedangkan tes menulis digunakan saat siswa menulis. Instrumen dalam penelitian ini yaitu instrumen yang digunakan sebagai pengukur variabel terikat yaitu lembar observasi dan tes menulis. Setiap instrumen penelitian melalui beberapa uji instrumen sehingga menunjukan hasil yang benarbenar valid.

Teknik analisis data yang digunakan adalah statistik deskriptif dan statistik inferensial melalui Uji-t. Analisis deskriptif digunakan untuk mengetahui tinggi rendahnya kualitas dari dua variabel yaitu model pembelajaran dan hasil belajar Bahasa Indonesia siswa yang dihitung melalui nilai rata-rata (mean), modus, median, standar deviasi, dan varians. Sedangkan, sebelum menggunakan statistik inferensial melalui Uji-t data harus diuji normalitas dan homogenitasnya. Kriteria pengujian data berdistribusi normal jika hitung < tabel, dengan taraf signifikan 5\% dan derajat kebebasannya $\mathrm{dk}=(\mathrm{k}-1)$. Sedangkan Kriteria pengujian jika $F \geq$ Ftabel maka sampel tidak homogen dan jika $F<$ Ftabel maka sampel homogen. pengujian dilakukan dengan taraf signikan 5\% dengan derajat kebebasan untuk pembilang V1 $=\mathrm{n} 1-1$ dan derajat kebebasan untuk penyebut $\mathrm{V} 2=\mathrm{n} 2-1$. Petunjuk dalam menggunakan rumus separated varians yaitu jika $\mathrm{n} 1=\mathrm{n} 2$ dan varians homogen, maka dapat digunakan rumus t-test, baik untuk separated maupun polledvarians, dengan $\mathrm{db}=\mathrm{n} 1+\mathrm{n} 2-2$ sedangkan jika $\mathrm{n} 1=\mathrm{n} 2$ dan tidak homogen, dapat digunakan salah satu rumus di atas; dengan $\mathrm{db}=\mathrm{n} 1-1$ atau $\mathrm{n} 2-1$ (bukan $\mathrm{n} 1+\mathrm{n} 2-2$ ). Jika H0 ditolak dan H1 diterima, maka dapat diinterpretasikan bahwa terdapat perbedaan hasil belajar Bahasa Indonesia yang signifikan antara kelompok siswa yang belajar menggunakan model pembelajaran Think Talk Write (TTW) dengan kelompok siswa yang belajar menggunakan model pembelajaran konvensional. Adanya perbedaan yang signifikan menunjukkan bahwa penerapan model pembelajaran Think Talk Write (TTW) berpengaruh terhadap hasil belajar Bahasa Indonesia siswa. 


\section{Results and Discussion}

Berdasarkan hasil penelitian, kegiatan post-test yang diberikan kepada 44 orang siswa pada kelompok eksperimen diperoleh data hasil belajar Bahasa Indonesia menunjukkan bahwa nilai tertinggi adalah 59 dan nilai terendah adalah 48. Berdasarkan hasil perhitungan yang telah dilakukan, maka ditetapkan banyak kelas adalah 6 dan panjang kelas adalah 2 . Data hasil belajar kelompok eksperimen mean $(\mathrm{M})=54,09$, median $(\mathrm{Md})=54,61$ dan modus $(\mathrm{Mo})=56,16$ Dari data hasil belajar kelompok eksperimen tersebut dapat dipaparkan bahwa modus lebih besar dari median dan median lebih besar dari mean (Mo $>M d>M$ ). Sebagian besar nilai cenderung tinggi. Hal ini dapat ditunjukkan dari frekuensi pada tabel distribusi frekuensi. Frekuensi relatif skor yang berada di atas rata-rata lebih besar dibandingkan frekuensi relatife skor yang berada di bawah rata-rata. Dengan kata lain, grafik di atas adalah grafik juling negatif.

Sedangkan mengacu pada tabel distribusi frekuensi data hasil belajar kelompok kontrol, dapat dideskripsikan mean (M), median (Md), dan modus (Mo) dari data hasil belajar kelompok kontrol, yaitu: mean $(\mathrm{M})=40.07$, median $(\mathrm{Md})=38,7$, dan modus $(\mathrm{Mo})=37,3$. Berdasarkan data hasil belajar kelompok kontrol di atas, dapat diketahui bahwa modus lebih kecil dari median dan median lebih kecil dari mean $(\mathrm{Mo}<\mathrm{Md}<\mathrm{M})$. Dengan kata lain, grafik di atas adalah grafik juling positif. Artinya, sebagian besar skor cenderung rendah. Kecenderungan skor ini dapat dibuktikan dengan melihat frekuensi relatif pada tabel distribusi frekuensi. Frekuensi relatif skor yang berada di atas rata-rata lebih kecil dibandingkan frekuensi relatif skor yang berada di bawah rata-rata. Kemudian dilakukan uji hipotesis untuk mengetahui pangaruh dari model pembelajaran yang diterapkan. Namun sebelum dilakukan uji hipotesis terlebih dahulu dilakukan uji prasyarat analisis data yaitu normalitas dan homogenitas. Rangkuman hasil uji normalitas disajikan pada Tabel 1.

Tabel 1. Rangkuman Hasil Uji Normalitas dan Hasil Uji Homogenitas

\begin{tabular}{llcccccc}
\hline No & Kelompok Data & $\chi^{2}$ & $\begin{array}{c}\text { Nilai Kritis } \\
\text { dengan Taraf } \\
\text { Signifikansi } \\
\mathbf{5 \%}\end{array}$ & Status & $\mathrm{F}_{\text {hit }}$ & $\begin{array}{c}\mathrm{F}_{\text {tab }} \text { Tengan } \\
\text { Taraf } \\
\text { Signifikansi } \\
5 \%\end{array}$ & Status \\
\hline 1 & $\begin{array}{l}\text { Post-test } \\
\text { Eksperimen }\end{array}$ & 4,2904 & 7,815 & Normal & 1,47 & 1,69 & Homogen \\
\hline 2 & Post-test Kontrol & 2,6812 & 7.815 & Normal & 1,47 & 1,69 & Homogen \\
\hline
\end{tabular}

Berdasarkan hasil perhitungan menggunakan rumus chi-kuadrat, diperoleh $\chi^{2}$ hit hasil post-test kelompok eksperimen adalah 6,3477 dan $\chi_{\text {tab }}^{2}$ pada taraf signifikansi $5 \%$ dan $\mathrm{dk}=$ 3 adalah 7,815. Hal ini berarti, $\chi^{2}$ hit hasil belajar Bahasa Indonesia kelompok eksperimen lebih kecil dari $\chi_{\text {tab }}^{2}\left(\chi_{h i t}^{2}<\chi_{t a b}^{2}\right)$, sehingga data skor hasil belajar Bahasa Indonesia kelompok eksperimen berdistribusi normal. Pada kelompok kontrol, $\chi^{2}$ hit hasil belajar Bahasa Indonesia kelompok kontrol adalah 2,6812 dan $\chi^{2}$ tab dengan taraf signifikansi 5\% dan $\mathrm{dk}=3$ adalah 7,815. Hal ini berarti, $\chi^{2}$ hit hasil belajar Bahasa Indonesia kelompok kontrol lebih kecil dari $\chi^{2}{ }_{t a b}\left(\chi^{2}{ }_{h i t}<\chi^{2}{ }_{t a b}\right)$, sehingga data hasil belajara Bahasa Indonesia kelompok kontrol berdistribusi normal. Selanjutnya rangkuman hasil uji homogenitas, diketahui $F_{\text {hit }}$ hasil belajar kelompok eksperimen dan kontrol adalah 1,47, sedangkan $F_{\text {tab }}$ pada $d b_{\text {pembilang }}=44, \mathrm{db}_{\text {penyebut }}=42$, dan taraf signifikansi $5 \%$ adalah 1,69 . Hal ini berarti, varians data hasil belajar Bahasa Indonesia kelompok eksperimen dan kontrol adalah homogen. Setelah data hasil belajar dinyatakan berdistribusi normal dan homogen, maka dilanjutkan dengan uji hipotesis. Rangkuman hasil uji hipotesis disajikan pada Tabel 2. 
Tabel 2. Rangkuman Hasil Uji-t

\begin{tabular}{|c|c|c|c|c|c|c|}
\hline Kelompok & $\mathbf{N}$ & db & $\operatorname{Mean}\left(\bar{x}^{-}\right)$ & $s^{2}$ & $\mathbf{t}$ hitung & $\mathbf{t}$ tabel \\
\hline Eksperimen & 44 & \multirow{2}{*}{84} & 25,32 & 2,86 & \multirow{2}{*}{35,71} & \multirow{2}{*}{2,000} \\
\hline Kontrol & 42 & & 17 & 3,14 & & \\
\hline
\end{tabular}

Berdasarkan tabel rangkuman analisis di atas, dapat diketahui $t_{\text {thitung }}=35,71$ dan $t_{\text {tabel }}=$ 2,000 untuk $\mathrm{db}=84$ pada taraf signifikansi $5 \%$. Berdasarkan kriteria pengujian, karena $t_{\text {hitung }}$ $>\mathrm{t}_{\text {tabel }}$ maka $\mathrm{H}_{0}$ ditolak dan $\mathrm{H}_{1}$ diterima. Artinya, terdapat perbedaan hasil belajar Bahasa Indonesia antara kelompok siswa yang dibelajarkan dengan model pembelajaran Think Talk Write $(T T W)$ berbantuan media gambar dan kelompok siswa yang dibelajarkan dengan model pembelajaran konvensional pada siswa kelas IV SD di Gugus III Kecamatan Gerokgak tahun pelajaran 2017/2018.

Hasil analisis data menyatakan bahwa terdapat perbedaan hasil belajar antara siswa yang terapkan dengan model pembelajaran Think Talk Write (TTW) berbantuan media gambar dengan siswa yang diterapakan model pembelajaran konvensional. Tinjauan ini didasarkan pada hasil uji-t dan rata-rata skor hasil belajar siswa. Analisis data menggunakan uji-t, diketahui $t_{\text {hitung }}=35,71$ dan $t_{\text {tabel }}$ pada taraf signifikansi $5 \%=2,000$. Hasil perhitungan tersebut menunjukkan bahwa $t_{\text {hitung }}$ lebih besar dari $t_{\text {tabel }}$ ( $t_{\text {hitung }}>t_{\text {tabel }}$ ), sehingga hasil penelitian adalah signifikan. Hal ini berarti, terdapat perbedaan hasil belajar antara kelompok siswa yang diterapkan dengan model pembelajaran Think Talk Write (TTW) berbantuan media gambar dengan kelompok siswa yang diterapkan model pembelajaran konvensional.

Sedangkan dari nilai rata-rata hasil belajar siswa yang mengikuti model pembelajaran Think Talk Write (TTW) berbantuan media gambar diperoleh angka sebesar 54,09 dan nilai rata-rata hasil belajar siswa yang mengikuti pembelajaran konvensional sebesar 40,07. Hal ini menunjukkan bahwa hasil belajar kelompok siswa yang diterapkan dengan model pembelajaran Think Talk Write (TTW) berbantuan media gambar lebih tinggi dibandingkan dengan kelompok siswa yang diterapkan dengan model pembelajaran konvensional. Terdapat beberapa hal yang dapat menjelaskan penyebab hasil belajar siswa dikelompok eksperimen lebih tinggi dibandingkan hasil belajar siswa dikelompok kontrol baik secara teoritis maupun secara empiris.

Secara teoritis model pembelajaran Think Talk Write (TTW) merupakan model pembelajaran yang mampu melatih keahlian berbahasa baik secara lisan dan tulisan dengan lancar (Huda, 2014). Model pembelajaran Think Talk Write (TTW) berbantuan media gambar juga merupakan salah satu model pembelajaran yang tepat diterapkan untuk meningkatkan hasil belajar siswa. Hal ini dikarenakan model pembelajaran ini membuat siswa menjadi lebih tertarik dalam mengikuti proses belajar mengajar dan terlibat aktif dalam memecahkan suatu masalah yang diberikan oleh guru sehingga proses pembelajaran lebih berpusat kepada siswa. Sadiman, dkk. 2009: 29 (dalam Yunita, 2017) menyatakan "di antara media pembelajaran, media gambar adalah media yang paling umum dipakai. Media gambar termasuk ke dalam media visual". Disamping mampu menggunakan alat-alat yang tersedia, guru juga dituntut untuk dapat mengembangkan keterampilan membuat media pembelajaran yang akan digunakannya apabila media tersebut belum tersedia. Sedangkan model pembelajaran konvensional yang diterapkan pada kelas kontrol lebih berpusat kepada guru (teacher centered). Secara teoritis, pembelajaran konvensional merupakan cara berinteraksi yang dipergunakan sejak dulu antara guru dan siswa dalam proses pembelajara atau biasa disebut metode pembelajaran tradisional atau disebut juga dengan metode ceramah (Djamarah, 1996). Dalam hal ini, secara teoritis pembelajaran konvensional menunjukkan model pembelajaran tradisional yang kurang maksimal dalam meningkatkan hasil belajar siswa. 
Secara empiris, kedua model pembelajaran tersebut memiliki perbedaan yang dapat dibandingkan dari cara prakteknya dalam proses pembelajaran. Pada model pembelajaran Think Talk Write (TTW) berbantuan media gambar siswa terlibat aktif dalam proses pembelajaran sehingga pembelajaran berpusat pada siswa (student center). Berbanding terbalik dengan proses pembelajaran dengan model konvesional siswa diberikan informasi oleh guru tanpa ikut berperan aktif dalam proses pembelajaran sehingga pembelajara lebih berpusat ke guru (teacher cantered).

Mencermati perbedaan dari penerapan kedua model tersebut baik secara teoritis maupun empiris, model pembelajaran Think Talk Write (TTW) berbantuan media gambar lebih mampu meningkatkan hasil belajar siswa jika dibandingkan dengan model pembelajaran konvensional.

Hasil temuan ini, didukung dengan penelitian yang dilakukan oleh Dewa Made Suma Pariana, dengan penelitiannya yang menunjukkan bahwa model pembelajaran Think Talk Write (TTW) berbantuan media gambar berpengaruh terhadap hasil belajar IPA pada siswa kelas. Hal ini sejalan dengan penelitian yang dilakukan oleh Ni Putu Tri Ariani yang menyatakan siswa yang mengikuti pembelajaran dengan model pembelajaran Think Talk Write (TTW) Terhadap Keterampilan Menulis Puisi memperoleh nilai rata-rata 92,88 sedangkan siswa yang mengikuti pembelajaran dengan model pembelajaran konvensional nilai rata-ratanya 4,40. Sehingga dapat disimpulkan bahwa terdapat perbedaan yang signifikan pada nilai karakter siswa kelas V semester II antara kelompok siswa yang dibelajarkan dengan model Think Talk Write (TTW) Terhadap Keterampilan Menulis Puisi dan kelompok siswa yang dibelajarkan dengan model pembelajaran konvensional. Penelitian yang dilakukan oleh Luh Putu Desy Ambari dalam penelitian yang memperoleh hasil belajar IPA 51,13 tergolong pada kreteria tinggi. Sedangkan siswa yang mengikuti pembelajaran dengan model pembelajaran konvensional memiliki hasil belajar IPA 39,54 tergolong kreteria rendah. Sehingga dapat disimpulkan bahwa terjadi perubahan yang signifikan pada nilai karakter siswa kelas V semester II antara kelompok siswa yang dibelajarkan dengan model pembelajaran Think Talk Write (TTW) dan kelompok siswa yang dibelajarkan dengan model pembelajaran konvensional. Penelitian yang dilakukan oleh Azizatul Khusna (Khusna, 2017) dengan penelitian yang memperoleh hasil belajar siswa pada kelas eksperimen diperoleh ratarata hasil pre-test sebesar 59,5 dan rata-rata post-test sebesar 74,5. Hasil ini menunjukan bahwa ada perbedaan hasil belajar yang signifikan antara siswa sebelum dan sesudah diterapkan dengan model pembelajaran Think Talk Write (TTW) berbantuan media CD Interaktif.

Dengan demikian dapat kita simpulkan bahwa secara teoritis model pembelajaran Think Talk Write (TTW) berbantuan media gambar berpengaruh terhadap hasil belajar siswa. Selain itu, model pembelajaran Think Talk Write (TTW) dapat dijadikan bahan acuan oleh peneliti berikutnya dalam mengangkat topik yang relevan. Secara Praktis, model pembelajaran Think Talk Write $(T T W)$ berbantuan media gambar dapat membantu guru mengatasi rendahnya hasil belajar siswa terutama dalam belajar Bahasa Indonesia. Untuk siswa, belajar dengan model ini dapat menarik lebih minat siswa untuk belajar di dalam kelas. Pengaplikasian pembelajaran model Think Talk Write (TTW) berbantuan media gambar memfokuskan keterlibatan siswa dalam menemukan sendiri pengetahuannya. Hal ini dapat dilihat dalam kegiatan diskusi kelompok siswa tanpa sadar mengasah kemampuan bahasanya dengan teman kelompoknya dengan mengungkapkan pendapat dan ide-ide pikirannya sedangkan guru hanya bertugas sebagai fasilitator dan motivator dalam pembelajaran.

Dalam penelitian ini, peneliti menemukan beberapa hambatan kecil. Dalam proses pembelajaran dalam kelas eksperimen ada beberapa siswa yang masih kurang konsentrasi dalam mengikuti proses pembelajaran dan hal itu sudah dapat diatasi dengan memberikan 
perhatian lebih kepada siswa tersebut. Namun, peneliti merasa permasalahan tersebut tidak begitu berarti dibandingkan dengan hambatan yang ditemukan dalam kelas kontrol. Dalam kelas kontrol masih banyak siswa yang tidak memperhatikan penjelasan dari guru. Siswa lebih cenderung bermain-main dengan teman sebangkunya. Selain itu terdapat pula siswa yang tertidur saat proses pembelajaran berlangsung.

Untuk penelitian berikutnya, diharapkan pengembangan dalam penerapan model Think Talk Write (TTW) berbantuan media gambar ini. Terutama dalam penggunaan media gambar bisa dibuat semenarik mungkin sehingga mampu menarik minat siswa untuk lebih memperhatikan materi. Media gambar dibuat lebih konkret dan diwarnai dengan warnawarna yang lebih cerah. Dalam tahap diskusi, guru harus memiliki kemampuan mengontrol suasana kelas, mendampingi dan membimbing masing-masing kelompok dalam menukarkan ide masing-masing sehingga mengurangi suasana kelompok yg ribut di dalam kelas atau siswa yang pasif. Dengan pengembangan tersebut diharapkan pemanfaatan model pembelajaran Think Talk Write (TTW) berbantuan media gambar mampu meningkatkan hasil belajar dalam segala jenjang pendidikan dan mata pelajaran yang lainnya.

Berdasarkan penelitian di atas menunjukkan bahwa model pembelajaran Think Talk Write $(T T W)$ berbantuan media gambar dapat memberikan pengaruh terhadap hasil belajar Bahasa Indonesia. Sehingga siswa dalam proses pembelajaran berperan aktif di dalam kelas. Menurut Huiker dan dan Laughin (Jaya, 2019) ada beberapa keunggulan metode pembelajaran Think Talk Write (TTW) berbantuan media gambar merangsang siswa untuk lebih aktif membangun pemahaman secara mandiri, memiliki tahapan-tahapan yang tidak terlalu sulit dan rumit lagi bagi siswa. Membangun pemahaman melalui berpikir, berbicara dan menulis. Pemahaman siswa mudah terbentuk melalui berbicara dan menulis. Dalam penelitian ini terdapat hasil belajar Bahasa Indonesia, siswa dalam proses pembelajaran sangat antusias dan berperan aktif sehingga keterkaitan penelitian ini dengan penelitian yang sudah ada adalah sama-sama meneliti tentang hasil belajar. Peneliti mengambil referensi dari penelitian yang sudah ada, sehinga penelitian di atas dapat terlaksana dengan baik.

\section{Conclusion}

Berdasarkan hasil pengujian hipotesis dan pembahasan, dapat peneliti nyatakan bahwa nilai rata-rata hasil belajar Bahasa Indonesia siswa yang mengikuti model pembelajaran Think Talk Write (TTW) berbantuan media gambar lebih tinggi dibandingkan dengan nilai rata-rata hasil belajar siswa yang mengikuti model pembelajaran konvensional. Sedangkan, dari hasil analisis yang dilakukan menunjukkan bahwa nilai $t$ hitung lebih besar dari t tabel. Kualifikasi hasil belajar Bahasa Indonesia siswa yang mengikuti model pembelajaran Think Talk Write (TTW) berbantuan media gambar berada pada kategori sangat tinggi sedangkan hasil belajar Bahasa Indonesia siswa yang mengikuti model pembelajaran konvensional berada pada kategori tinggi. Dari hasil tersebut, maka dapat disimpulkan bahwa pembelajaran dengan model pembelajaran Think Talk Write (TTW) berbantuan media gambar berpengaruh positif terhadap hasil belajar Bahasa Indonesia siswa kelas IV SD di Gugus III Kecamatan Gerokgak Kabupaten Buleleng tahun pelajaran 2017/2018. Berdasarkan hasil penelitian adapun beberapa saran yaitu melalui penerapan model ini, siswa diharapkan lebih mampu berinteraksi dan terlibat aktif dalam proses pembelajaran sehingga dari keterlibatannya langsung dapat menemukan pengalaman dan pengetahuan baru dan hasil belajar siswa dapat meningkat. Guru dituntut mampu melakukan inovasi pembelajaran sesuai dengan kondisi kelas dengan memilih model dan media pembelajaran yang kreatif dan menyenangkan sehingga dapat menarik minat siswa untuk mengikuti proses pembelajaran. Kepada sekolah, khususnya Sekolah Dasar (SD) diharapkan model pembelajaran Think Talk Write (TTW) berbantuan media gambar ini dapat dijadikan salah satu model pembelajaran yang wajib diterapkan dalam proses pembelajaran di dalam kelas. Peneliti lain hendaknya 
memperhatikan kelemahan-kelemahan yang dialami dalam penelitian ini sebagai bahan pertimbangan dalam perbaikan dan penyempurnaan penelitian berikutnya dengan judul yang sama.

\section{References}

Agustina, D. (2017). Perbandingan Hasil Belajar Siswa Menggunakan Media Gambar Bergerak Dengan Gambar Diam. Jurnal Pembelajaran Fisika, 5(3).

Ainiyah, Q. (2017). Penerapan Model Pembelajaran Kooperatif Tipe Think Talk Write pada Materi SPLDV Kelas VIII MTs Nurul Islam Pongangan. Universitas Muhammadiyah Gresik.

Amirul, F. (2017). Pengertian Model Pembelajaran Think Talk Write. http://fatkhan.web.id/pengertian-model-pembelajran-think-talk-write/

Arsyad, A. (2009). Media Pembelajaran Cetakan IV. Rajawali Pers: Jakarta.

Badudu, J. S. (1996). Pintar Berbahasa Indonesia 1. Jakarta: Balai Pustaka.

Djamarah, S. B. (1996). Strategi Belajar Mengajar. Jakarta: PT. Rineka Cipta.

Fitri, Y. (2016). Pengaruh Model Pembelajaran Kooperatif Tipe Think Talk Write Berbantuan Media Gambar Terhadap Keterampilan Menulis Karangan Argumentasi Siswa Kelas X SMA Negeri 5 Padang. Pendidikan Bahasa Indonesia, 5(2), 548554.

Hikmawati, R. K. (2013). Keefektifan Strategi Pembelajaran TTW (Think Talk Write) berbantuan LKPD terhadap Kemampuan Berpikir Kritis Peserta Didik Kelas X. Universitas Negeri Semarang.

Huda, M. (2014). Model-Model Pengajaran Dan Pembelajaran. Yogyakarta: Pustaka Pelajar.

Jaya, M. H. (2019). Penerapan Pembelajaran Think Talk Write (TTW) untuk Meningkatkan Hasil Belajar Matematika Siswa Kelas X EI 2 SMK Negeri 2 Singosari. Semnas SENASTEK Unikama 2019, 2.

Khusna, A. (2017). Penerapan model pembelajaran think talk write (TTW) berbantu media cd interaktif pada mata pelajaran IPA terhadap hasil belajar siswa. Jurnal Penelitian Ilmu Pendidikan, 10(2), 136-148.

Kurniawati, A. (2018). Pengaruh Model Cooperative Learning Tipe Think Talk Write (TTW) Terhadap Pemahaman Siswa pada Mata Pelajaran Ekonomi di Sekolah Menengah Atas Negeri 3 Pekanbaru. Universitas Islam Negeri Sultan Syarif Kasim Riau.

Mustika, D. (2016). Pengembangan Media Pembelajaran Interaktif Mata Pelajaran Merakit Personal Computer Kelas X SMK Sejahtera. Universitas Negeri Jakarta.

Nasional, P. M. P. (2006). Standar Isi Bahasa Indonesia Untuk Sekolah Dasar. Jakarta: Depdiknas. Nomor.

Putra, N. A. (2011). Penggunaan media gambar seri untuk meningkatkan keterampilan menulis narasi pada mata pelajaran Bahasa Indonesia siswa kelas IV SDN Moahino Kabupaten Morowali. Jurnal Kreatif Online, 2(4).

Santyasa, I. W. (2007). Landasan Konseptual Media Pembelajaran. Makalah. Universitas Pendidikan Ganesha.

Susanto, A. (2013). Teori Belajar \& Pembelajaran di Sekolah Dasar. Jakarta: Kencana. 
Yunita, I. (2017). Korelasi antara Penggunaan Media Gambar dengan Hasil Belajar Siswa dalam Pembelajaran IPS Kelas IV. Tanjungpura University. 